Nina S. Studer

\title{
Remembrance of Drinks Past: Wine and Absinthe in Nineteenth-century French Algeria
}

\begin{abstract}
This chapter draws links between the colonisation of French Algeria in the nineteenth century and the production, and especially the consumption, of alcohol. The military confrontation with abstentious Muslims prompted many nineteenth century French authors to highlight the correlation between French identity and certain alcoholic drinks. In France's collective memory, wine and absinthe were linked with the conquest of Algeria, with drinks both serving as an aide-de-mémoire for settlers returned to France and, more importantly, as an emblematic symbol for Algeria itself. Whether a person consumed or abstained from alcohol became one of the principal dichotomies in the settler worldview, encapsulating perceived cultural differences, with those Muslim men who began to drink alcohol after France's brutal conquest of Algeria often framed as embracing French civilisation or as mimicking French culture. Even French authors who feared the overconsumption of alcohol amongst French settlers and the spread of alcoholism amongst local communities agreed that alcohol played a positive role in the colonisation of Algeria, as settlers both relied on it for comfort and used it to reinforce social contacts. This chapter shows how descriptions of the drinking habits of the French in colonial Algeria helped to define the group identity of a dominant minority surrounded by an oppressed majority, while also examining why later French colonisers so often chose to recall with nostalgia the early colonisation of Algeria (i.e. the $1830 \mathrm{~s}$ to 1850s) through metaphors connected to alcohol, with French culture likened to vines taking root on North African soil, fortifying conquered territory.
\end{abstract}

Drinking alcohol, especially wine and to a lesser degree absinthe, was seen as quintessentially French in the nineteenth century. French people produced and consumed these beverages, while the drinks themselves were seen as symbols of their homeland. ${ }^{1}$ Since Roland Barthes' pioneering work in the 1950s,

1 See, for example: Patricia Prestwich, Drink and the Politics of Social Reform: Anti-Alcoholism in France since 1870 (Palo Alto: Society for the Promotion of Science and Scholarship, 1988), 1. It should be added here that this Frenchness was clearly gendered, class-based and urban-centred, and that not all drinks were understood to impart Frenchness to women, the lower classes and

Ә OpenAccess. (c) 2022 Nina S. Studer, published by De Gruyter. (cc) BY-NC-ND This work is licensed under the Creative Commons Attribution 4.0 International License. https://doi.org/10.1515/9783110655315-008 
scholars have analysed the proclivity to equate France with particular drinks and the role that alcohol played in the formation of French identity. ${ }^{2}$ Barthes stated in his 1957 monograph Mythologies that France understood wine to be first and foremost French, comparable to how tea was framed in Britain. ${ }^{3}$ More broadly, a scholarly consensus has emerged that what people eat and drink informs how they see both themselves and others. ${ }^{4}$

In France's collective memory, a handful of alcoholic drinks were linked with Algeria in the nineteenth century. These beverages served as both an aide-de-mémoire for settlers returned to France - i.e. Proustian madeleines ${ }^{5}$ - and, more importantly, as an emblematic symbol for Algeria itself. After a prolonged and deadly conflict that began in 1830 when the French army arrived on the North African coast, Algeria legally became a part of France in 1848. The indigenous population suffered considerable losses of property, land, and life, and Muslims remained marginalised in terms of citizenship and full civil rights. The colonisation of Algeria included the establishment of Algerian vineyards, physical proof of French civilisation occupying the region. Algerian Muslims identified vine-

those living in the countryside. Detailed analysis of this important distinction falls beyond the scope of this chapter, but forms part of the author's broader research into the drinking habits of people in the colonial Maghreb. The sources consulted for this chapter focus on French settlers who were male and, if not otherwise indicated, middle class.

2 There is an existing literature on the role that alcohol played in France's self-image, focusing mainly on the importance of wine for the French national identity. Kolleen M. Guy, When Champagne Became French: Wine and the Making of a National Identity (Baltimore: John Hopkins University Press, 2003); Kolleen M. Guy, "Rituals of Pleasure in the Land of Treasures: Wine Consumption and the Making of French Identity in the Late Nineteenth Century," in Food Nations: Selling Taste in Consumer Societies, ed. Warren Belasco and Philip Scranton (New York: Routledge, 2002), 34-47; Marion Demossier, Wine Drinking Culture in France: A National Myth or a Modern Passion (Cardiff: University of Wales Press, 2010).

3 Roland Barthes, Mythologies (Paris: Editions du Seuil, 1957), 69. Barthes, however, also criticised wine production in Algeria as forcing Muslims to produce grapes for wine, rather than wheat for their own consumption. Ibid., 70.

4 Thomas M. Wilson, "Food, Drink and Identity in Europe: Consumption and the Construction of Local, National and Cosmopolitan Culture," in Food, Drink and Identity in Europe, ed. Thomas M. Wilson (Amsterdam/New York: Rodopi, 2006), 25-26. On the interconnections between identity and drinking, see also Thomas M. Wilson, "Drinking Cultures: Sites and Practices in the Production and Expression of Identity," in Drinking Cultures: Alcohol and Identity, ed. Thomas M. Wilson (Oxford: Berg Publishers, 2005), 1-24.

5 The term "Proust's madeleine," which refers to a sensory trigger that evokes memory, comes from Marcel Proust's 1907 In Search of Lost Time and his famous passage about madeleine cakes that unlocked childhood memories. 
yards, as did the French, as symbols of colonialism. ${ }^{6}$ After independence, Algerian Muslims uprooted most of the vineyards in an active undertaking of decolonisation, turning them into wheat fields, thus actively and pre-emptively undoing some potential lieu de mémoires of French colonialism on Algerian soil. ${ }^{7}$

Absinthe also held particular associations with Algeria that can be traced to rations of the beverage issued to French soldiers during the initial conquest of Algeria in the 1830s and 1840s. Officials believed the beverage could clean unpotable water and thus protect from disease. French soldiers, who generally had not encountered absinthe before their military service in Algeria, came to like the strong, sweet, cold drink and took their newfound beverage of choice - imbued with symbolism - back to the mainland with them. As Jad Adams stated in his history of absinthe: "Absinthe therefore emerged as a tonic that was patriotic, associated with vigour, the army and the overseas empire." ${ }^{8}$ An example of this almost wistful remembrance can be found in a highly Orientalist travel account written by the Belgian author Léon Souguenet, describing Algeria:

\begin{abstract}
It's the holy hour of the apéritif. The small town exudes the subtle aroma of absinthe, social liquor if there ever was one; the terraces of the cafés flow over onto the roads. One speaks as in France; there is a light brouhaha [a noisy uproar]; there is a motley crowd of bourgeois, soldiers, officers. One watches the magnificently lazy natives pass by, sitting on unfortunate donkeys, whose wounds they never bandage, and women bundled in their white veils. ${ }^{9}$
\end{abstract}

Many such travel accounts explicitly connect alcoholic drinks with French Algeria and were written to evoke a certain feeling of nostalgic fernweh or colonial grandeur in their French readers in the Métropole and in the colonies. From the 1880 s onwards, these accounts had started to reframe the initial period of

6 On the decline of vineyards in Algeria after 1962, see Kolleen M. Guy, "Culinary Connections and Colonial Memories in France and Algeria," Food and History 8, no. 1 (2010): 227; Willy Jansen, "French Bread and Algerian Wine: Conflicting Identities in French Algeria," in Food, Drink and Identity. Cooking, Eating and Drinking in Europe since the Middle Ages, ed. Scholliers Peter (Oxford: Bloomsbury Publishing, 2001), 202; Giulia Meloni and Johan Swinnen, "The Rise and Fall of the World's Largest Wine Exporter - and its Institutional Legacy," Journal of Wine Economics 9, no. 1 (2014): 4.

7 Guy, "Culinary Connections," 229. See also: Owen White, The Blood of the Colony: Wine and the Rise and Fall of French Algeria (Cambridge/London: Harvard University Press, 2021), 215, 220. $8 \mathrm{Jad}$ Adams, Hideous Absinthe: A History of the Devil in a Bottle (London: I. B. Tauris, 2008), 4. 9 Despite their geography, Tunisia, Algeria and Morocco were framed as part of "the Orient" in nineteenth century France. The quoted passage comes from Léon Souguenet, Route de Timimoun: Heures religieuses (Brussels: Oscar Lamberty, 1914), 103. All English translations by the author. 
the military conquest and occupation, from 1830 to the 1870s, as a transfer of civilisation, symbolised by the introduction of alcohol, which "oiled" the colonial machinery, so to speak. In France, people nostalgically recalled stays in Algeria through accounts of shared glasses of absinthe consumed on terraces of French bars in the coastal cities and in the houses of family members, friends and acquaintances. Thanks to these accounts, a metropolitan reader might have felt that he was able to experience French Algeria with his daily glass of absinthe: Drinking absinthe, in this context, could be construed as indicative of both imperialism and patriotism.

This chapter addresses the following questions: Did French settlers' production and consumption of alcohol help the French to establish and maintain colonial rule in Algeria? Or did the spread of alcohol - among the colonisers as well as among the colonised Algerian Muslims - obstruct the French from maintaining colonial rule? Building from this, how did European authors remember and judge the role of alcohol during the time of the military conquest of Algeria and the subsequent establishment of a French settler society? This chapter will show that French attitudes toward different groups' consumption of alcohol in the situation coloniale can shed light on how the French saw colonisation in Algeria more broadly. French self-identification with certain forms of alcohol expressed itself as a useful tool to reinforce and maintain colonial rule. ${ }^{10}$ French colonisers often chose to remember the early colonisation of Algeria through metaphors connected to alcohol, and recollections of French drinking habits in Algeria were used to define the group identity of a dominant minority surrounded by an oppressed minority. From the 1880s onwards, the presence of locally produced, French-owned alcohol in Algeria was remembered as a vindication of colonialism itself; a sentiment that only increased in the first half of the $20^{\text {th }}$ century.

This chapter is based on nineteenth century French settler memoirs, travel accounts and medical publications that mention the consumption of alcohol in the context of the colonisation of Algeria. These sources often represented French Algeria through accounts of drinking, of watching others drink, of how drinks were prepared and of their offering and being offered drinks. Settler memoirs and travel accounts were written by both professional authors and amateurs for a wide audience in the motherland, hungry for the exoticism and adventures

10 These questions have been studied in other colonial contexts. See, for example: Harald Fischer-Tiné, "Liquid Boundaries: Race, Class and Alcohol in Colonial India," in A History of Alcohol and Drugs in Modern South Asia: Intoxicating Affairs, ed. Harald Fischer-Tiné and Jana Tschurenev (Abingdon: Routledge, 2014), 89-115; Deborah Toner, "Maize, Alcohol, and Cultural Identity in Colonial Mexico" (MA Thesis, University of Warwick, 2006). 
that journeying outside of France allegedly brought. ${ }^{11}$ A large segment of this audience saw the colonies as direct proof of France's glory and read these settler memoirs and travel accounts with this assumption in mind. Equally, a wide range of French authors interpreted the consumption of alcohol as a sign of civilisation, of whiteness and of a very specific French identity. They pointed to differences between their own eating and drinking habits and those of colonised Algerians as shorthand to describe perceived cultural differences. Many interpreted the dissemination of their own habits as a victory over the customs of the colonised. Authors of these sources - those who could afford to travel and who chose to document their experiences living in Algeria - were in general both educated and middle- to upper-class. ${ }^{12}$ The settler memoirs and travel accounts used for this chapter reached a relatively small audience, yet these metropolitan readers accepted the emphasis that these authors placed on the importance of alcohol in the colonisation of this foreign soil and adapted this idea into a wider discourse pertaining to how the establishment of a French settler colony in Algeria was remembered in France.

Muslim religious and legal tractates that discuss the illegality of alcohol span centuries - far beyond what can be discussed in this chapter. ${ }^{13}$ Nonetheless, it can be said that a consensus existed among most nineteenth century Algerian Muslims, based on an interpretation of Suras 5:90 and 5:91, that the Qur'an forbade alcohol. They therefore objected to the introduction and glorification of alcohol and vineyards by the French. On the other hand, despite this prohibition, some Muslims consumed alcohol in Algeria before the French conquest in the region, and not all Muslims rejected the alcohol made available to

11 On the long history of French travel accounts, see Elisabeth A. Fraser, "Books, Prints, and Travel: Reading in the Gaps of the Orientalist Archive," Art History 31, no. 3 (2008): 342-367. 12 Jacques Boucher de Perthes, for example, was already a famous archaeologist by the time he wrote his travel account in 1859, while Amédée Hennequin was a well-established lawyer at the date of the publication of his report in 1857. Other travel accounts were written by people affiliated with academic and scientific institutions, for example Étienne Bailly in 1868, who was a Corresponding Member of the Imperial and Agricultural Society for Agriculture of France, or Ernest Fallot in 1887, who was the Secretary for the Society for Geography in Marseille. Étienne Bailly, Études sur l'Algérie en 1855 pendant un voyage exécuté par M. Bailly (Paris: Imprimerie de F. Malteste, 1868), title page; Ernest Fallot, Par-delà la Méditerranée: Kabylie, Aurès, Kroumirie (Paris: E. Plon, Nourrit et $\mathrm{C}^{\mathrm{ie}}$, 1887), title page.

13 Due to the limitations that these sources impose as well as space constraints, discussion of how Algerian Muslims depicted and evaluated alcohol during the nineteenth century is absent from this chapter. 
them by colonisation, as will be discussed further in this chapter.$^{14}$ Additionally, some tried to obtain an economic advantage by producing or trading in alcohol.

French medical experts wrote for two very different audiences - either for other medical experts or for the settlers themselves. The authors, doctors travelling through or living in Algeria, wrote scientific papers about their professional experiences in Algeria and handbooks specifically focused on the climate and circumstances of that colony. They hoped that, with the help of these manuals, the settlers would remain healthy and avoid illness, especially those with limited access to medical institutions. These doctors intended to write recommendations suited to every European living in Algeria. Their advice about what to drink and how much to drink was usually gendered and class-based, but rarely differentiated between the cities and the countryside or between the coast and the desert. Despite intending their publications to reach settlers in remote areas, the descriptions of drinking habits in these medical manuals often assumed easy access to shops, cafés and bars. In addition, these doctors played an important role in settler communities. In her 2016 article, historian Charlotte Ann Chopin described French doctors in Algeria as both the prime representatives of French whiteness on Algerian soil and as individuals who embodied the "emergent values of local settler culture." ${ }^{\prime 15}$ Their mentions of alcohol should therefore be interpreted as a direct recommendation of healthy living from people cast as role models in these colonial contexts to other potentially less "civilised" white people. The medical descriptions of alcohol consumption in Algeria were generally seen as settler guidelines for successful "white" living in the colony.

This chapter comprises two parts. The first, Frenchness in a Bottle, analyses how colonial accounts linked alcohol to nostalgia for the early colonial period a time of French soldiers and civilians allegedly making the land "habitable" for Europeans. It examines colonial source material that portrays beverages like wine and absinthe favourably, i.e. authors who interpreted alcohol as a vaunted symbol of Frenchness in general or French imperialism in particular. In the second part, Beyond "All Limits of Plausibility," contrasting opinions will be analysed, namely the fear that alcohol would be detrimental to the colonisation

14 On Algerian Muslims' consumption of alcohol prior to French conquest in the region, see, for example: Rudi Matthee, “Alcohol in the Islamic Middle East: Ambivalence and Ambiguity,” Past and Present 9 (2014): 106. Other authors disagree and claim that pre-colonial Algeria had been alcohol free. See, for example: Christopher Cumo, “Algeria," in The Sage Encyclopedia of Alcohol: Social, Cultural, and Historical Perspectives, ed. Scott C. Martin (New York: Sage Publishing, 2015), 117-118.

15 Charlotte Anne Chopin, “Embodying 'the New White Race': Colonial Doctors and Settler Society in Algeria, 1878-1911," Social History of Medicine 29, no. 1 (2016): 20. 
of Algeria in light of the fact that many people, colonisers and colonised alike, consumed it without moderation.

\section{Frenchness in a Bottle}

French qualities were often understood to be mirrored in certain drinks, foremost among them wine. The association of wine with Frenchness became even more pronounced in French Algeria than in France itself following the occupation of the African territory in the 1830s, as the newcomers were confronted with groups who had traditionally chosen to not consume wine. ${ }^{16}$ This interlinking of metropolitan identity with wine manifested through behaviour such as making the beverage one's daily drink of choice in a predominantly Muslim territory. ${ }^{17}$ This not only continued a drinking habit to which many settlers had been accustomed since childhood in France, but also, in the Algerian context, drinking wine was a way to proudly display one's Frenchness. ${ }^{18}$

Consequently, the production and consumption of wine significantly shaped the identity of French settlers in Algeria. ${ }^{19}$ Anthropologist Willy Jansen, for example, explained in a chapter on "French Bread and Algerian Wine" that particular foods and drinks helped to establish and construct social identities in colonial contexts and that the preparation and consumption of food and drink delineated boundaries between people. In colonial Algeria, this meant that both the consumption of and abstinence from certain foods and drinks were variously classed as Muslim, Jewish or French. In Jansen's view, wine was the product that most clearly defined the French in Algeria. She further justified this as-

16 Michalak and Trocki describe in their article on "Alcohol and Islam" that the abstinence from a product can be as identity-building as its consumption. Laurence Michalak and Karen Trocki, "Alcohol and Islam: An Overview," Contemporary Drug Problems 33 (2006): 555-556. 17 American historian Kolleen M. Guy in her 2003 book When Champagne Became French has examined the importance of champagne as a "symbol of France" in the French national identity. See Guy, When Champagne Became French, 5, 33-34.

18 On the issue of French people accustomed to drinking wine from childhood, see, for example, Octave Saint-Vel, Hygiène des Européens dans les climats tropicaux, des créoles et des races colorées dans les pays tempérés (Paris: Adrien Delahaye, 1872), 43-44; Adolphe Bonain, L'Européen sous les tropiques: Causeries d'hygiène coloniale pratique (Paris: Henri Charles-Lavauzelle, 1907), 238-239.

19 The geographer Hildebert Isnard, for example, highlighted this phenomenon in his 1947 study of wine in Algeria. He stated: "The culture of the vine has shaped, in this way, the mentality of the Algerian colonist." Hildebert Isnard, "Vigne et colonisation en Algérie (18801947),” Annales. Économies, Sociétés, Civilisations 2, no. 3 (July-Sept. 1947): 295. 
sociation by stating that the overt consumption of wine was almost exclusively a French habit in the colonial context: "The political and economic elite [among the colonised Algerians] would privately enjoy the 'cuvée du president,' but this did not make wine acceptable as a marker of ascendancy. For the majority of Algerian Muslims, it is not worthy of emulation, as it is a symbol of lewdness and lack of self-control."20

In the French understanding of Islam, Muslims simply did not drink alcohol. They therefore could not profit from the positive consequences of wine drinking like the French. Most French authors ignored local alcohol production, such as fig or date liquors and palm wine, which existed both before and during the colonisation of the region, and interpreted alcohol solely as an import from France. ${ }^{21}$ As such, alcohol symbolised not only France but specifically their colonising power on hostile Algerian soil. In this narrative, alcohol arrived with the French army and flourished on the North African coast. The spread of alcohol in Algeria therefore served as a triumphant narrative of colonisation and was often remembered as such. Inspired by the presence of Algeria at the Universal Exhibition in Paris of 1889 and impressed above all by the array of wines on display from the region, Raoul Bergot wrote a book about the colony that attributed cultural ascent to the intoxicant: "In the three rooms of wine samples, there was a magnificent proof of the modern conquest by French civilisation of this barbarian land. Each bottle of wine represented a small vineyard and often a domain of one hundred hectares." Bergot went on to say that other, more colourful rooms, full of Orientalist fantasies, were more spectacular than those containing the wine samples, so that many visitors had, to his regret, neglected to take in the importance of Algerian wines. He then explained "that the three rooms of this bare exposition, expressed in their simplicity a giant leap made by progress, thanks to the French race, on the other side of the Mediterranean."22

Bergot thus measured the "progress" of French colonisation by the spread of wine and vineyards in Algeria - and he was not alone in this regard. By claiming vineyards as a symbol of colonialism, the images of the war of conquest and the

20 Jansen, "French Bread," 214.

21 Only a few colonial accounts mentioned local forms of alcohol whose basic existence contradicted this narrative of colonisation through alcohol. See, for example, Lucien Raynaud, "Alcool et alcoolisme au Maroc," Annales d'Hygiène Publique et de Médecine Légale 497, no. 3 (1902): 211, 214. The idea that alcohol had been unknown in Algeria before the advent of the French was still proposed as late as 1937, for example by the psychiatrist Jean Sutter: Jean Sutter, "L'épilepsie mentale chez l'indigène nord-africain (étude clinique)," (Med. Thesis, University of Algiers, 1937), $75-76$.

22 Raoul Bergot, L'Algérie telle qu'elle est (Paris: Albert Savine, 1890), 1. 
subsequent violent colonisation of the region were supplanted by that of farmers peacefully cultivating fields and growing a culturally significant product. Based on this, many nineteenth century accounts imply that alcohol in general and wine more specifically "colonised" Algeria. This sentiment seems to have been so common among the settlers that it was turned into a humorous piece of conventional wisdom, a shared anecdote, recounted by both settler authors and travellers in their publications. Ernest Fallot, for example, in his 1887 travel account described how the military conquest was the first step in the colonisation of Algeria, followed by settlers who sold liquid "necessities" to both the military and the settlers:

A few years later, if business is satisfactory, they built a stone house [i.e. a shop in a stone house] in order to be more at ease and to return to civilised life. The combination of several of these canteeners' houses gives birth to a village, and this is what has made [people] jokingly say that absinthe colonised Algeria. ${ }^{23}$

In this jest, shared among French settlers, the military conquest of Algeria and the colonial authority imposed through violent repression, that resulted in famine, displacement and epidemics which decimated the indigenous population, was trivialised as nothing more than the necessary first step in the ecological and economic development of the region.

Even more important than the idea of alcohol having "conquered" Algeria together with the French army was the notion that certain drinks substantially helped France to maintain its colonial presence. Many French settlers and European travellers imagined that both alcoholic and non-alcoholic drinks played an active role in the colonising of Algeria. The renowned French hygienist Apollinaire Bouchardat, for example, wrote in his Manual of Medical Matters in 1856: "Without coffee, our Algeria would be uninhabitable." ${ }^{24}$ While medical publications often credited coffee with having made Algeria habitable and French soldiers stronger, this bizarre agency was more widely ascribed to certain alcoholic drinks, such as wine, absinthe and mixed drinks like champoreau. ${ }^{25}$

23 Fallot, Par-delà la Méditerranée, 29. The same expression of "colonising through absinthe" being something deeply problematic can be found in other publications. See, for example, Eugène Poiré, La Tunisie française (Paris: E. Plon, Nourrit et C $C^{\text {ie }}$ Imprimeurs-Éditeurs, 1892), 133. 24 Apollinaire Bouchardat, Manuel de matière médicale, de thérapeutique comparée et de pharmacie, Vol. 1 (Paris: Germer Baillière, 1856), 304. The author is currently working on an article on this issue under the working title Coffee Drinking as a Military Strategy: The Service Rendered by Coffee in the French Conquest of Algeria.

25 Champoreau, a mix of coffee, milk and various forms of alcohol, shared the title of most popular alcoholic beverage in Algeria with wine and absinthe. On the popularity of champoreau, 
In the context of wine specifically, vineyards were thought to safeguard both the livelihoods of the settlers and the economic interests of France. By the 1890s, experts declared that the coasts of Algeria, Tunisia and Morocco offered the perfect economic investment for vintners. ${ }^{26}$ Kathleen Guy argued in 2003 that proponents of colonialism in France claimed that viticulture proved the economic utility of colonies. ${ }^{27}$ French colonists in Algeria succeeded in making wine one of the colony's major exports, even as the proportion of Muslim vineyard owners declined. Historian Susanna Barrows analysed the distribution of vineyards in colonial Algeria and found that while in 1864 "indigenous vineyards accounted for nearly a third of the vines," this figure "fell below $10 \%$ in the first years of the twentieth century."28

French-owned vineyards in Algeria demonstrated that French settlement had metaphorically and literally taken root in the country. This idea that vineyards and wine helped to make the colony of Algeria more stable and inhabitable for French settlers only solidified over the years. In the early twentieth century, for example, French authors looked back nostalgically to the period of the planting of the vineyards in Algeria and framed these acts as an essential part of the establishment of the settler colony. This can be seen, for example, in Pierre Pinaud's 1933 doctoral dissertation on Alcoholism among the Arabs in Algeria, in which he stated that "Wine is, at present, one of the great riches of Algeria. [...] In many parts of Algeria, vines were only planted to ensure the safety of the French settlers." 29 This interpretation of wine as an important agent in the French colonial occupation of Algeria was germane to the Orientalist assumption that prior to French settlement, the region had been in a state of decay under Muslim rule. Such accounts often referred to the fact that the Maghreb had once been known as the breadbasket of Rome with vineyards flourishing in the region. This richness had been destroyed, in this narrative, by devotedly abstinent Muslims. ${ }^{30}$

see, for example Jacques Boucher de Perthes, Voyage en Espagne et en Algérie, en 1855 (Paris: Treuttel et Würtz, 1859), 508. Bailly, Études, 158-159.

26 See, for example, Sylvère Leroux, Traité de la vigne et le vin en Algérie et en Tunisie, Vol. 2 (Blida: A. Maugin, 1894), 7.

27 Guy, "Culinary Connections," 231.

28 Susanna Barrows, "Alcohol, France and Algeria: A Case Study in the International Liquor Trade,” Contemporary Drug Problems 11 (1982): 536. See also Keith Sutton, “Algeria’s Vineyards: A Problem of Decolonisation," Méditerranée 65 (1988): 55.

29 Pierre-Alfred-Hippolyte-André-René Pinaud, "L’alcoolisme chez les Arabes en Algérie” (Med. Thesis, University of Bordeaux, 1933), 17.

30 See, for example, Albin Lafont, Les dangers de l'alcoolisme (Lyon: Bureau de la Société de Tempérance, 1893), 5; Guy, "Culinary Connections,” 231-232. 
Yet prior to the military conquest of the region, Muslims had used much of the land that the French subsequently converted into vineyards to produce wheat. This neglect of the cultivation of a necessity (wheat) for the colonised in favour of the cultivation for a luxury product (wine) for the coloniser, drew criticism from many mid-twentieth century commentators, among them JeanPaul Sartre in 1964, who stated:

Between 1927 and 1932, wine-growing increased by 173,000 hectares, more than half of which was taken from the Muslims. However, Muslims do not drink wine. On this land that was stolen from them they grew cereals for the Algerian market. This time it was not only the land that was taken from them; by planting vines there, the Algerian population was deprived of its staple food. Half a million hectares, taken from the best land and entirely devoted to wine-growing, were reduced to unproductiveness and as good as wiped out for the Muslim masses. ${ }^{31}$

Contrary to Sartre's claims about Muslim abstinence, after the conquest of Algeria, with the increased availability of cheap imported and locally produced alcohol, the majority of French authors reported that some Algerian Muslims had started to drink. ${ }^{32}$ Colonial publications framed Algerian Muslims developing a taste for alcohol as an ideological decision with far-reaching political and social consequences. French authors suggested that Muslims who chose to drink alcohol must necessarily be on France's side, while those who refused to drink alcohol opposed France, thus conflating alcohol consumption and political and religious identity. Most observers agreed that when Algerian Muslims chose to drink French alcohol, it meant much more than them simply choosing a drink, which can only be truly understood when one considers the notion of alcohol as a symbol of Frenchness. French judge Jean Le Roy explicitly mentioned this connection between Muslim alcohol consumption and an assumed assimilation of Frenchness in his 1911 travel account. He described encounters with Muslims who had allegedly reframed the prohibition of alcohol in the Qur'an to permit their own moderate consumption. Le Roy saw advantages to this

31 Jean-Paul Sartre, Colonialism and Neocolonialism, trans. Terry McWilliams (London/New York: Routledge, 2001), 37.

32 As there are no numbers for the precolonial consumption of palm wine, wine, fig and date liquor in Algeria, it is not possible to reconstruct if there was an actual increase in alcohol consumption or if that was just the perception of the French authors or if this was a French construction of Muslim alcohol consumption rooted in stereotype rather than evidence. On the history of these precolonial drinks in Tunisia, see Nessim Znaien, "Les raisins de la domination: Histoire sociale de l'alcool en Tunisie à l'époque du Protectorat (1881-1956)” (Doctoral Thesis, Sorbonne University, 2017), 108-111. 
way of thinking: "Mahomet outlawed the abuse of wine, but not the moderate use of this liquor. This view is particularly favourable to the societal rapprochement between natives and Europeans, and in fact, when the native Muslims are in the company of Frenchmen, I have always seen them drink wine and liquors without any appearance of scruples."33

Some colonial authors reported their attempts to encourage Algerian Muslims to drink as part of the colonial effort to transform them into Frenchmen. A psychiatrist, Dr. Pierre Rouby, claimed in a paper presented at the 1895 Congress of Psychiatrists and Neurologists of France and of Francophone Countries that he had initially supported the idea of converting water-drinking Algerian Muslims to wine in order to bring them closer to French civilisation: "I have offered them [his field workers] from it [alcohol], asking them to drink from it, to please me, to not be rude to me; they always refused, a categorical refusal, coming from a deep conviction: 'God forbids it."'34 Rouby thus admitted at a prestigious academic conference that he had encouraged Muslims to drink alcohol, despite knowing that their religion prohibited it. The motivation behind his attempt becomes clear if the reader assumes that Rouby considered alcohol a symbol of France. Field labourers' alcohol consumption would have suggested their acceptance of French customs. By drinking the wine or liquor that Rouby offered, they would have demonstrated their gradual assimilation to French culture - but they "rudely" refused and thus chose to remain true to their faith. His personal attempt at colonising through alcohol had, in this instance, failed.

After the war of independence and the decolonisation of Algeria, many nostalgic memoirs connected settler experiences in Algeria to the planting of and caring for vineyards, as well as to the daily "holy hour of absinthe," as mentioned by Souguenet above. ${ }^{35}$ Before the prohibition of absinthe in 1914, the French in Algeria would regularly consume it each day at roughly five o'clock, which they called the "hour of absinthe" or "green hour." This was either

33 Jean Le Roy, Deux ans de séjour en petite Kabilie: Un peuple de barbares en territoire français (Paris: Augustin Challamel, 1911), 57-58.

34 Pierre Rouby, "De l'alcoolisme en France et en Algérie," in Congrès des Médecins Aliénistes et Neurologistes de France et des Pays de Langue Française, ed. F. Devay (Paris: G. Masson, 1895), 240.

35 Souguenet, Route de Timmimoun, 103. See also A. Villacrose, Vingt ans en Algérie: Ou tribulations d'un colon racontées par lui-même: la colonisation en 1874, le régime militaire et l'administration civile, mours, coutumes, institutions des indigènes, ce qui est fait, ce qui est à faire (Paris: Challamel aîné, 1875), 150 -151; Camille Viré, En Algérie: Une excursion dans le département d'Alger (Paris: C. Bayle, 1888), 91-92. Authors who strongly argued against the consumption of absinthe also used the vocabulary of the "hour of absinthe." See, for example, Victor Anselmier, De l'empoisonnement par l'absinthe (Paris: Imprimerie de J. Claye, 1862), 11. 
done in public spaces, such as cafés or bars, or in private spaces, i.e. the houses of settlers. After the prohibition of absinthe, this habit was transferred to the consumption of different anisettes. The pleasant company, the relaxation, the jokes and stories told by friends and neighbours, the relief this minority felt in company with each other, the ritual of letting the cold water slowly drip into the alcohol, and the drink itself, were all combined into a wistful image of everything that was "good" in French Algeria. This evocative image very often made it into the travel accounts and settler memoirs and shaped how life in French Algeria was seen and remembered back home.

\section{Beyond "All Limits of Plausibility"}

Not all European observers interpreted "colonisation through alcohol” as a positive development. Criticism of the interconnections between colonialism and alcohol largely focused on the fact that people in mainland France perceived settlers in most colonies as inveterate drinkers. ${ }^{36}$ While overconsumption of alcohol was considered a problem across France's colonial empire, the settlers in Algeria were regularly singled out as the biggest culprits, akin to the infamy in Britain of Kenya's "Happy Valley" set. An anonymous account published in 1907, for example, lamented that "absinthe played, in [Algeria's] colonisation, a malevolent role, and its consumption [among settlers] exceeds all limits of plausibility." ${ }^{37}$ People in the metropole generally assumed that overconsumption by French settlers in Algeria negated the positive effects associated with alcohol. One concern stemmed from how they imbibed the beverages that symbolised France "wrongly." Settlers drank immoderately, at the wrong times, and were especially fond of strong liquors instead of alcohol deemed "hygienic," such as wine, beer and cider. Absinthe drinkers were especially deplored as wasting

36 It should be added, however, that it is entirely questionable whether the alcohol consumption of the European settlers in French Algeria actually exceeded consumption levels in mainland France, as alcoholism also presented a very significant - if often neglected - problem in the Métropole in the nineteenth century. On the issue of alcoholism in nineteenth century France, see, for example: Guy, "Rituals of Pleasure," 38-39; Patricia E. Prestwich, "Female Alcoholism in Paris, 1870 - 1920: The Response of Psychiatrists and of Families," History of Psychiatry 14, no. 3 (2003): 324; Patricia E. Prestwich, "Temperance in France: The Curious Case of Absinth,” Historical Reflections/Réflexions Historiques 6, no. 2 (1979): 301.

37 Anonymous, Un soldat d'Afrique: l'Algérie (Limoges: Librairie du XXe siècle, 1907), 200. See also Victor Demontès, "La grande, la moyenne et la petite colonisation en Algérie," in Congrès de l'Afrique du Nord tenu à Paris du 6 au 10 Octobre 1908: Compte rendu des travaux, ed. Charles Depincé, Vol 1 (Paris: Augustin Challamel, 1909), 172. 
their time drinking instead of working the fields to advance and strengthen French colonial presence. In 1875, A. Villacrose, a French settler in Algeria, described settlers "who are more often playing boules and drinking absinthe than working their field" as one of the major obstacles to extending French power in the region. ${ }^{38}$ Botanist Jules Rémy in an 1858 travel account summarised his impressions of the settlers in Algeria: “Algeria needs fewer publicans and small shopkeepers; fewer idlers and absinthe drinkers; fewer disreputable people, and more real workers. I say this with a deep sense of shame: there are in Algeria, with regards to the proportion of its population, more scoundrels than in California." 39

It was believed that the pieds-noirs' overconsumption directly affected the power of French colonisation of the region, as drunken settlers were thought unable to fulfil their role in France's mission civilisatrice. Their behaviour set a poor example for the colonised and additionally rendered them physically more likely to succumb to the fevers of the region. Inebriation inhibited the cultivation of fields and thus limited the push to extend France's control inland. In the Métropole, it was feared that the settlers might not even be able to defend themselves against attacks from the colonised. Amédée Hennequin in his 1857 Conquest of Algeria described the situation around Algiers in 1841. In some villages, settlers were so scared of attack by the colonised that they "dared not even go a few steps from their homes to cultivate the earth, and that colonisation, thus paralysed by terror, had hardly any other representatives than feverish publicans, selling absinthe to the soldiers." 40 For many French authors in the Métropole, the absinthe drinkers - both military and civilian - and the publicans selling absinthe and other alcoholic beverages became shameful symbols of French colonialism in Algeria. The European settlers in Algeria, it was feared in France, "succumbed to fever, laziness, absinthe and debts." ${ }^{41}$ Many authors even claimed that the settler society in Algeria was so dependent on alcohol that it could not function abstemiously. ${ }^{42}$ Villacrose, for example, wrote in his 1875 travel ac-

38 Villacrose, Vingt ans, 362.

39 Jules Rémy, Lettres d'un voyageur à M. L.G.-G. (Châlons: Imprimerie de T. Martin, 1858), 5. 40 Amédée Hennequin, La conquête de l'Algérie (Paris: Charles Douniol, 1857), 47.

41 This quote regarding pieds-noirs neglecting their duties can be found in the 1895 account of the famous French author and journalist Robert Charles Henri Le Roux, who wrote under the name Hugues Le Roux about his experiences as a French settler in Algeria. Hugues Le Roux, Je deviens colon: Mœurs algériennes (Paris: Calmann Lévy, 1895), 155.

42 It should be noted that not all commentators expressed such vehement criticism. Some criticised this notion of French settlers in Algeria being inveterate absinthe drinkers and defended the drinking habits of the pieds-noirs as suitable to the hard work and harsh climate in Algeria. 
count that both trade agreements and social visits in Algeria were fuelled by alcohol: "The settlers in Algeria are unfortunately, for the vast majority, people who only visit each other and talk to each other with a glass in hand."43

Dire consequences for French settlers in the region would ensue from their unvarnished dependence on alcohol, warned many in the medical community. Presenting the grave consequences of maintaining two communities with very different levels of alcohol consumption - "sober Arabs" and "alcoholic settlers" - in a paper on Alcoholism in France and in Algeria, given in 1895 in Paris, Pierre Rouby connected these fears of French settlers failing in their duties to the question of alcohol:

From the observation of this fact [i.e. the existence of the following two distinct groups], sober Arabs, alcoholic settlers, we can draw, gentlemen, social and political conclusions, and show that danger threatens our Algerian colony, if no strong medicine comes to cure the disease. When you have lived for some time in Algeria, even when you have arrived there [as an] Arabophile, if you look around you, if you talk with various inhabitants, if you study things closely, it is not long before you notice that from the point of view of French colonisation, you must support the settler, fortify him, help him, because in him lies the future of French Algeria. For the Arab, on the other hand, it is not long before you recognise that he will never be French, he would need to convert; but not one Arab since the conquest has changed religion. [...] Mahomet has told them to treat as an enemy all that that is not Muslim; [...] they wait for a favourable opportunity to take their country back; they would do it tomorrow, as they tried in 1870, if they had any chance of winning. They are enemies, and, additionally, they are six times more numerous than the settlers. ${ }^{44}$

Rouby thus framed the overconsumption of alcohol by French settlers, which he saw as deeply problematic, as one front in the perpetual war of coloniser against colonised in North Africa. He argued that the colonised already possessed the numerical advantage and that because they refused to drink French alcohol, whereas the French settlers were often drunk, Muslim Algerians gained a further advantage - they were sober and strong, while the settlers were weakened by their excesses.

Yet this narrative was complicated by the spread of alcoholism among the Algerian Muslims after the conquest. Despite Rouby's categorical claim of their general abstinence, many were described as enthusiastically adapting the French custom of the "hour of absinthe." French observers frequently deplored the perceived rising levels of alcohol consumption among the Algerian Muslims

See, for example, Anonymous, La fin d'une légende, ou la vérité sur l'arabe, par un vieil Algérien (Bel-Abbès: Imprimerie de Lavenue, 1892), 166.

43 Villacrose, Vingt ans, 353.

44 Rouby, "De l'alcoolisme," 241. 
for similar reasons that commentators criticised settlers' drinking habits: alcoholism caused medical problems and diminished the labour force. Ironically, it was also believed that alcohol rendered Algerian Muslims potentially dangerous towards the colonisers - precisely what Rouby feared "sober Arabs" would become. This discourse about "colonisation by alcohol" having a negative influence on the colonised - and consequently on the economic and security interests of the colonisers - was also voiced in other colonial contexts. In 1909, A. Kermorgant, for example, wrote an article for the Bulletin of the Society of Exotic Pathology about the situation of Alcoholism in French Colonies, in which he proclaimed that: "Nothing is more disastrous than this system of colonisation by alcohol [...]." 45

Fears of alcoholism spreading among the colonised would seem to directly contradict the positive associations of alcohol for French Algeria discussed above. Yet this can be explained through the difference between drinking alcohol and drinking alcohol excessively. Many authors who feared the rising number of Muslim alcoholics nonetheless accepted alcohol as a positive symbol of France when consumed in moderation. Crucially, only the French possessed this latter capacity, according to many French authors. This group of commentators believed that Algerian Muslims lacked self-control and thus drank immoderate amounts of strong liquors instead of moderate amounts of "hygienic" alcoholic beverages such as wine, cider and beer. ${ }^{46}$ Assuming that all Muslim alcohol consumption led to alcoholism, they therefore strongly disagreed with those who welcomed the rising alcohol consumption of Algerian Muslims as a sign of assimilation into French culture.

45 A. Kermorgant, "L’alcoolisme dans les colonies françaises," Bulletin de la Société de Pathologie Exotique 2, no. 6 (1909): 331.

46 On the alleged affinity of Algerian Muslims for strong liquors such as absinthe, see, for example, Louis Vignon, La France en Algérie (Paris: Hachette et $\left.C^{\mathrm{ie}}, 1893\right), 410$; Auguste Voisin, “Souvenirs d'un voyage en Tunisie (1896)," Annales Médico-Psychologiques 4 (1896): 90. This differentiation between liquors and good, "hygienic" alcohol had far-reaching consequences. Later during the colonisation of the region, there were attempts to limit and control the alcohol consumption of Muslim Algerians. Dr H. Foley of the Pasteur Institute of Algeria, for example, described such measures in a 1938 article on medical issues in Southern Algeria, in which he described a 1917 decree on the suppression of public drunkenness and on the control of places selling alcohol. He added, however, that the Muslim consumption of "hygienic beverages" such as beer and wine could not be controlled as "hygienic beverages" could not be limited. Henry Foley, "Aperçu de la pathologie indigène dans les territoires du Sud algérien,” In La vie dans la région désertique Nord-tropicale de l'ancien monde, ed. L. Aufrère et al. (Paris: P. Lechevalier, 1938), 302. 
Other colonial sources ridiculed even moderate consumption of alcohol among Muslim Algerians. Indeed, very few colonial publications described Muslims in Algeria drinking alcohol in a positive light. ${ }^{47}$ Many accounts openly mocked the colonised Muslims who allegedly sought to appear assimilated and civilised through their alcohol consumption, but whose behaviour was invariably portrayed as a clownish imitation by European observers. The English writer W.G. Windham, for example, wrote a book about his travels through Spain and North Africa published in 1862, in which he described the results of civilisation in Algeria:

From the general prosperity, I, of course, except the Moors and Arabs, who will never, I believe, adopt European civilisation; they seem to recoil before it, like the wild beasts of their native deserts. The French people certainly pointed out to me in the towns one or two Europeanised Arabs, and laughed at the idea of their ever becoming 'Français'. From what I saw, the natives merely adopted the vices without the good qualities of the dominant race. If to be civilised consists in sitting in the cafés, drinking absinthe, playing cards, and speaking bad French, I certainly saw one or two most unquestionable specimens of the Arab adaptability to Gallic impressions; but, with the exception of these brilliant results, I never saw the least token of intercourse between the Moors and their conquerors; indeed, each nation may be said entirely to ignore the existence of the other. ${ }^{48}$

It appears that from Windham's specific perspective - as a non-Muslim, nonFrench writer - both imitator and imitated were to blame for the lack of "progress" in Algeria: the colonisers set a bad example and sections of the local population copied them badly. As a consequence, alcohol-drinking Muslims, proof of the "Arab adaptability to Gallic impressions," seem to have been the only signs of assimilation observable to Windham. In this case, the alcohol consumption of the Algerian Muslims Wyndham observed demonstrated the failure of French colonisation through alcohol. Drinking corrupted and debased these Algerian Muslims instead of turning them into Frenchmen and thus furthering the French colonisation of the region.

The aforementioned immoderation, which the colonised Muslim Algerians allegedly shared with the French settlers, the so called pieds-noirs, in both choice of drink and amount consumed had the consequence that any conjectured assimilation that might result was always flawed. This whole discourse surround-

47 In fact, most European observers lamented and ridiculed the idea expressed by a few people like Le Roy that giving Muslims alcohol could be a means of fraternisation between colonisers and colonised. See, for example: Vignon, La France en Algérie, 481.

48 W.G. Windham, Notes in North Africa: Being a Guide to the Sportsman and Tourist in Algeria and Tunisia (London: Ward and Lock, 1862), 47. Emphasis in the original. 
ing assimilation through the consumption of French drinks left the Algerian Muslims with a distinct lack of agency, as many colonial writers agreed with Wyndham and thought that the colonised Muslims had only taken to drinking alcohol to imitate the poor example set by the pieds-noirs. Indeed, the settlers were often more directly blamed for the rising alcohol levels among Muslims than the Muslims who actually consumed alcohol.

\section{Conclusion}

This chapter examined how French colonial settlers and travellers in Algeria thought about alcohol in the nineteenth century, with a specific focus on what influence they believed intoxicants had on the colonisation of the region. Even though many of the authors covered in this chapter spent very limited time as travellers in Algeria, their fernweh-soaked accounts had an enormous influence on how life in Algeria was understood back in France. The spread of different kinds of alcohol and the planting of vineyards in Algeria were proudly glorified as symbols of colonisation by many French authors covering the early colonial period from the 1830s to the 1870s, the time during which a European settler society was established in Algeria through a brutal war of conquest. Later authors were able to look back on this early period as the successful foundation of the French colonisation of Algeria.

The discourse around alcohol in nineteenth-century Algeria was deeply influenced by nostalgia for the "glory" of the conquest of Algeria in France and for French ideals and civilisation in Algeria. Yet the role that drinks were perceived to play in the many recollections of French Algeria was much more complex than that of simply the Proustian madeleines evoking a wide range of emotions and memories. Even those French commentators who saw in the spread of alcoholism a tangible danger to the continuation of the colony agreed that wine, beer, absinthe and other beverages had played a significant role in the colonisation of Algeria, as settlers had relied heavily on them for comfort and to cultivate social contacts.

While there was a high degree of ambivalence in the French colonial publications around the question of whether alcohol assisted or hindered French colonial rule in Algeria, this lack of consensus was always linked to the issue of overconsumption. Excessive drinking turned alcohol from an allegedly useful tool of colonialism into a danger that threatened its very foundation and was linked to questions of identity in the colonial discourse. To those in the motherland, French settlers who drank too much were no longer considered French but rather pieds-noirs, with all the connotations of laziness and immoderation that 
this sobriquet entailed. They had lost touch with their French identity, which, it was argued, would have given them the moderation necessary to refrain from consuming excessive amounts of alcohol. They had to be retaught by French doctors how to be French and how to drink alcohol in a civilised, sensible French way in order to be successful white colonists. Only if they reconnected with their "true" French identity could they be expected to further the colonial mission. Algerian Muslims, on the other hand, tried, in the eyes of French observers, to become French through their alcohol consumption. The fact that they drank too much, and, at times, the wrong drinks demonstrated their failure in that endeavour.

Much of the discussion concerning alcohol in Algeria concerned the extent of its influence and the moral questions connected with identity-linked moderation. However, this discussion did not address the basic question of whether alcohol could, in fact, impact the colonial project. Alcohol in general and wine in particular were seen as symbols of a particularly French identity. In the context of Algeria, certain drinks were portrayed as valiant "fighters" for France's colonial interests, conquering North African soil with vineyards that pushed settlers deeper into a landscape "pacified" by the military. There is, of course, no actual agency in the substance of alcohol but it is telling to contrast these surprising claims regularly attributed to alcoholic drinks with descriptions of North Africans - even if it is only in a jocular way. In publications by French settlers and travellers who waxed nostalgic about their memories of Algeria, the agency of the European drinkers was transferred to the drink. Meanwhile, no matter what they consumed, Muslims' drinking habits drew criticism: to drink water implied a stubborn refusal of France and unwillingness to change, adapt or progress. Yet the actual consumption of alcohol by Muslims yielded no plaudits for assimilating, adapting or developing new tastes but only condemnation for badly imitating the worst behaviour of the French. Such descriptions highlight the power imbalance of the colonial situation. The question of agency was turned on its head, however, when it came to alcoholism. Negative issues surrounding alcohol drinking were also connected to overconsumption, a character trait that both pieds-noirs and Algerian Muslims allegedly shared. Consequently, the blame for all the negative consequences of alcoholism was not ascribed to the drinks - and thus not to the country that they symbolised - but to the individual drinkers. This dual view allowed people across the Mediterranean to remember French Algeria longingly when they drank a glass of wine or absinthe, without blemish to the drinks, to French Algeria, or to France.

Representing French colonisation of Algeria through metaphors connected to wine and absinthe - instead of the military or colonial medicine, for example - helped colonialism seem beneficial in the eyes of the French readers in the 
Métropole, some of whom were very critical of France's colonialism, and in the eyes of French settlers, whose fears were assuaged by either the jolliness or the grandeur of these narratives. To French settlers in Algeria, confronted with the reality of being among the minority that suppressed the colonised majority, alcohol consumption helped to create a system of sociability and engender a feeling of safety. Drinking hours dictated when and where one could meet other settlers - wine during meals and coffee after meals in the houses of friends and relatives; apéritifs in the afternoons and early evenings in the bars and cafés. The existence of these French drinks further created a feeling of familiarity in a land far from home in which they often felt threatened and beset. ${ }^{49}$ Drinking alcohol not only defined the French identity of the settlers in a foreign context, it also allowed them to unwind and to remember and celebrate their French way of living, absent friends, neighbours and family members across the Mediterranean. Each glass of wine directly connected them to their memories of a distinctly French way of life; one that most of them had been part of in their recent past, and that they still felt they belonged to despite the physical distance.

To the French in the Métropole, on the other hand, accounts of settlers sipping absinthe on the terraces of the cafés in the middle of an Orientalist tableau - obviously based more on the expectations of the writers than on reality painted a picture of Algeria that was both excitingly foreign yet reassuringly French. Statistics about the spread of French vineyards and numbers of the production of Algerian wines were evidence of the success of France's colonising mission. What better proof of harmlessness and success could there be than the spread of French vineyards on the other side of the sunny Mediterranean?

\section{Bibliography}

Adams, Jad. Hideous Absinthe: A History of the Devil in a Bottle. London: I. B. Tauris \& Co. Ltd., 2008.

Anonymous. La fin d'une légende, ou la vérité sur l'arabe, par un vieil Algérien. Bel-Abbès: Imprimerie de Lavenue, 1892.

Anonymous. Un soldat d'Afrique: l'Algérie. Limoges: Librairie du XXe siècle, 1907.

Anselmier, Victor. De l'empoisonnement par l'absinthe. Paris: Imprimerie de J. Claye, 1862.

Bailly, Étienne. Études sur l'Algérie en 1855 pendant un voyage exécuté par M. Bailly. Paris: Imprimerie de F. Malteste, 1868.

Barthes, Roland. Mythologies. Paris: Editions du Seuil, 1957.

Barrows, Susanna. "Alcohol, France and Algeria: A Case Study in the International Liquor Trade.” Contemporary Drug Problems 11 (1982): 525-543.

49 See: Rouby, "De l'alcoolisme,” 241. 
Bergot, Raoul. L'Algérie telle qu'elle est. Paris: Albert Savine, 1890.

Bouchardat, Apollinaire. Manuel de matière médicale, de thérapeutique comparée et de pharmacie. Vol. 1. Paris: Germer Baillière, 1856.

Boucher de Perthes, Jacques. Voyage en Espagne et en Algérie, en 1855. Paris: Treuttel et Würtz, 1859.

Bonain, Adolphe. L'Européen sous les tropiques: Causeries d'hygiène coloniale pratique. Paris: Henri Charles-Lavauzelle, 1907.

Braudel, Fernand. Civilisation matérielle, économie et capitalisme, XVe-XVIIle siècle: Les structures du quotidien. Paris: Armand Colin, 1979.

Chopin, Charlotte Anne. “Embodying 'the New White Race': Colonial Doctors and Settler Society in Algeria, 1878-1911." Social History of Medicine 29, no. 1 (2016): 1-20.

Cumo, Christopher. "Algeria." In The Sage Encyclopedia of Alcohol: Social, Cultural, and Historical Perspectives, edited by Scott C. Martin, $117 \mathrm{ff}$. New York: Sage Publishing, 2015.

Demontès, Victor. "La grande, la moyenne et la petite colonisation en Algérie.” In Congrès de l'Afrique du Nord tenu à Paris du 6 au 10 Octobre 1908: Compte rendu des travaux, edited by Charles Depincé, Vol 1, 150-174. Paris: Augustin Challamel, 1909.

Demossier, Marion. "The Quest for Identities: Consumption of Wine in France." Anthropology of Food (2001). Accessed 18 December 2020, http://journals.openedition.org/aof/1571.

Demossier, Marion. Wine Drinking Culture in France: A National Myth or a Modern Passion. Cardiff: University of Wales Press, 2010.

Fallot, Ernest. Par-delà la Méditerranée: Kabylie, Aurès, Kroumirie. Paris: E. Plon, Nourrit et $\mathrm{C}^{\mathrm{ie}}, 1887$.

Fischer-Tiné, Harald. "Liquid Boundaries: Race, Class and Alcohol in Colonial India." In A History of Alcohol and Drugs in Modern South Asia: Intoxicating Affairs, edited by Harald Fischer-Tiné and Jana Tschurenev, 89-115. Abingdon: Routledge, 2014.

Foley, Henry. "Aperçu de la pathologie indigène dans les territoires du Sud algérien." In $L a$ vie dans la région désertique Nord-tropicale de l'ancien monde, edited by Léon Aufrère et al., 275-305. Paris: P. Lechevalier, 1938.

Fraser, Elisabeth A. "Books, Prints, and Travel: Reading in the Gaps of the Orientalist Archive." Art History 31, no. 3 (2008): 342-367.

Guy, Kolleen M. "Rituals of Pleasure in the Land of Treasures: Wine Consumption and the Making of French Identity in the Late Nineteenth Century." In Food Nations: Selling Taste in Consumer Societies, edited by Warren Belasco and Philip Scranton, 34-47. New York: Routledge, 2002.

Guy, Kolleen M. When Champagne Became French. Wine and the Making of a National Identity. Baltimore: John Hopkins University Press, 2003.

Guy, Kolleen M. "Culinary Connections and Colonial Memories in France and Algeria." Food and History 8, no. 1 (2010): 219-236.

Hennequin, Amédée. La conquête de l’Algérie. Paris: Charles Douniol, 1857.

Isnard, Hildebert. "Vigne et colonisation en Algérie (1880-1947)." Annales. Économies, Sociétés, Civilisations $2^{\text {nd }}$ Year, no. 3 (July-Sept. 1947): 288-300.

Jansen, Willy. "French Bread and Algerian Wine: Conflicting Identities in French Algeria." In Food, Drink and Identity. Cooking, Eating and Drinking in Europe since the Middle Ages, edited by Peter Scholliers, 195-218. Oxford: Bloomsbury Publishing, 2001. 
Kermorgant, A. "L’alcoolisme dans les colonies françaises." Bulletin de la Société de Pathologie Exotique 2, no. 6 (1909): 330-340.

Lafont, Albin. Les dangers de l'alcoolisme. Lyon: Bureau de la Société de Tempérance, 1893.

Le Roy, Jean. Deux ans de séjour en petite Kabilie: Un peuple de barbares en territoire français. Paris: Augustin Challamel, 1911.

Le Roux, Hugues. Je deviens colon: Mœurs algériennes. Paris: Calmann Lévy, 1895.

Leroux, Sylvère. Traité de la vigne et le vin en Algérie et en Tunisie. Vol. 2. Blida: A. Maugin, 1894.

Matthee, Rudi. "Alcohol in the Islamic Middle East: Ambivalence and Ambiguity." Past and Present (2014): $100-25$.

Meloni, Giulia, and Johan Swinnen. “The Rise and Fall of the World's Largest Wine Exporter and its Institutional Legacy." Journal of Wine Economics 9, no. 1 (2014): 3-33.

Michalak, Laurence, and Karen Trocki. "Alcohol and Islam: An Overview." Contemporary Drug Problems 33 (2006): 523-562.

Pinaud, Pierre-Alfred-Hippolyte-André-René. “L’alcoolisme chez les Arabes en Algérie.” Med. Thesis, University of Bordeaux, 1933.

Poiré, Eugène. La Tunisie française. Paris: E. Plon, Nourrit et $C^{\text {ie }}$, Imprimeurs-Éditeurs, 1892.

Prestwich, Patricia E. "Temperance in France: The Curious Case of Absinth." Historical Reflections/Réflexions Historiques 6, no. 2 (1979): 301-319.

Prestwich, Patricia E. Drink and the Politics of Social Reform: Anti-Alcoholism in France since 1870. Palo Alto: Society for the Promotion of Science and Scholarship, 1988.

Prestwich, Patricia E. "Female Alcoholism in Paris, 1870-1920: The Response of Psychiatrists and of Families." History of Psychiatry 14, no. 3 (2003): 321- 336.

Raynaud, Lucien. "Alcool et alcoolisme au Maroc." Annales d'Hygiène Publique et de Médecine Légale 497, no. 3 (1902): 211-223.

Rémy, Jules. Lettres d'un voyageur à M. L.G.-G. Châlons: Imprimerie de T. Martin, 1858.

Rouby, Pierre. "De l'alcoolisme en France et en Algérie." Congrès des Médecins Aliénistes et Neurologistes de France et des Pays de Langue Française. Paris: G. Masson, 1895: 237-250.

Saint-Vel, Octave. Hygiène des Européens dans les climats tropicaux, des créoles et des races colorées dans les pays tempérés. Paris: Adrien Delahaye, 1872.

Sartre, Jean-Paul. Colonialism and Neocolonialism. London/New York: Routledge, 2001.

Souguenet, Léon. Route de Timmimoun: Heures religieuses. Brussels: Oscar Lamberty, 1914.

Sutter, Jean. "L'épilepsie mentale chez l'indigène nord-africain (étude clinique)." Med. Thesis, University of Algiers, 1937.

Sutton, Keith. “Algeria’s Vineyards: A Problem of Decolonisation.” Méditerranée 65 (1988): $55-66$.

Thierry, H. "Étude sur les pratiques et superstitions médicales des Marocains et sur l'influence de la médecine française au Maroc.” Med. Thesis, University of Paris, 1917.

Toner, Deborah. "Maize, Alcohol, and Cultural Identity in Colonial Mexico." MA Thesis, University of Warwick, 2006.

Vignon, Louis. La France en Algérie. Paris: Hachette et $C^{\text {ie }}, 1893$.

Villacrose, A. Vingt ans en Algérie: Ou tribulations d'un colon racontées par lui-même: la colonisation en 1874, le régime militaire et l'administration civile, mœurs, coutumes, institutions des indigènes, ce qui est fait, ce qui est à faire. Paris: Challamel aîné, 1875.

Viré, Camille. En Algérie: Une excursion dans le département d’Alger. Paris: C. Bayle, 1888. 
Voisin, Auguste. “Souvenirs d'un voyage en Tunisie (1896)." Annales Médico-Psychologiques 4, $54^{\text {th }}$ Year (1896): $89 \mathrm{f}$.

White, Owen. The Blood of the Colony: Wine and the Rise and Fall of French Algeria. Cambridge/London: Harvard University Press, 2021.

Wilson, Thomas M. "Drinking Cultures: Sites and Practices in the Production and Expression of Identity." In Drinking Cultures: Alcohol and Identity, edited by Thomas M. Wilson, 1-24. Oxford: Berg Publishers, 2005.

Wilson, Thomas M. "Food, Drink and Identity in Europe: Consumption and the Construction of Local, National and Cosmopolitan Culture." In Food, Drink and Identity in Europe, edited by Thomas M. Wilson, 11-29. Amsterdam/New York: Rodopi, 2006.

Windham, W.G. Notes in North Africa: Being a Guide to the Sportsman and Tourist in Algeria and Tunisia. London: Ward and Lock, 1862.

Znaien, Nessim. "Les raisins de la domination: Histoire sociale de l’alcool en Tunisie à l'époque du Protectorat (1881-1956)." Doctoral Thesis, Sorbonne University, 2017. 
